\title{
Vulnerability to climate change in three hot spots in Africa and Asia: key issues for policy-relevant adaptation and resilience- building research
}

\author{
Ken De Souza • Evans Kituyi • Blane Harvey • \\ Michele Leone $\cdot$ Kallur Subrammanyam Murali • \\ James D. Ford
}

Received: 31 July 2014/ Accepted: 17 January 2015/Published online: 13 March 2015

(c) The Author(s) 2015. This article is published with open access at Springerlink.com

\begin{abstract}
Providing sound evidence to inform decisionmaking that considers the needs of the most vulnerable to climate change will help both adaptation and development efforts. Such evidence is particularly important in climate change "hot spots", where strong climate signal and high concentrations of vulnerable people are present. These hot spots include semiarid regions and deltas of Africa and Asia, and glacier- and snowpack-dependent river basins of South Asia. In advance of a major research effort focusing on these three hot spots, studies were commissioned to
\end{abstract}

Electronic supplementary material The online version of this article (doi:10.1007/s10113-015-0755-8) contains supplementary material, which is available to authorized users.

K. De Souza

United Kingdom Department for International Development,

London, UK

e-mail: K-Desouza@dfid.gov.uk

E. Kituyi $(\bowtie) \cdot$ M. Leone

International Development Research Centre, Regional Office for

Sub-Saharan Africa, Nairobi, Kenya

e-mail: ekituyi@idrc.ca

M. Leone

e-mail: mleone@idrc.ca

B. Harvey

International Development Research Centre, Ottawa, Canada

e-mail: bharvey@idrc.ca

K. S. Murali

International Development Research Centre, Asia Regional

Office, Delhi, India

e-mail: kmurali@idrc.ca

J. D. Ford

Department of Geography, McGill University, Montreal, QC, Canada

e-mail: james.ford@mcgill.ca identify and characterize the current status of knowledge in each on biophysical impacts, social vulnerability, and adaptation policy and practice. The resulting seven papers are brought together in this special edition, with this editorial introduction providing background on these hot spots, the program through which the studies were commissioned, and an overview of the papers that follow.

Keywords Climate change - Vulnerability - Hot spots . Adaptation $\cdot$ Resilience $\cdot$ Africa $\cdot$ Asia

\section{Introduction}

Climate change is widely predicted to have significant and far-reaching impacts, with differences in vulnerability and exposure to these impacts arising from non-climate stressors and multi-dimensional inequalities. Poorer developing countries and their populations are likely to suffer disproportionately from these impacts (Smith et al. 2001; Mertz et al. 2009). In many parts of the developing world, the poor already struggle to cope with current variability in climate. While the likelihood of limiting global temperature increase to $2^{\circ}$ is now considered very low, even a $2^{\circ}$ rise in temperature is likely to have a significant and detrimental impact on regions home to large numbers of poor people (World Bank 2012; Dimitrov 2010). Although people and societies have adapted to climate variability for thousands of years, it is the increased pace and scale of change that poses significant challenges (Loarie et al. 2009).

Adaptation will be required to alleviate the worst effects of climate change and help build resilience, especially for the poorest and for those who live in the most vulnerable regions of the world (Costello et al. 2009; World Bank 2012). A "business as usual" approach to adaptation will 
no longer be sufficient in the face of the scale and severity of the projected changes (UNEP 2012). Recent estimates suggest that the costs of adaptation to a $2-3{ }^{\circ} \mathrm{C}$ rise in temperature range from US $\$ 25$ billion per year to well over US $\$ 100$ billion between 2010 and 2030 (Fankhauser 2010). For example, recent generation of adaptation cost studies suggest that African economies are facing costs of US $\$ 20-30$ billion per year by 2030 at the latest (Fankhauser and Schmidt-Traub 2011). Although some mechanisms are being set up to finance actions to respond to the challenges posed by climate change (see Biagini et al. 2014), it is important to tackle the uncertainty associated with programming for a changing climate early on; otherwise, there is a risk of taking not enough, too much, or the wrong type of action (Ranger 2013).

Given the issues noted above, more and better evidence, provided in accessible formats, is needed to support decision-making on adaptation, particularly in areas where poor people's livelihoods are most threatened by a changing climate. To address this need, the United Kingdom's Department for International Development (DFID) and Canada's International Development Research Centre (IDRC) set up a research program in 2012 named the Collaborative Adaptation Research Initiative in Africa and Asia (CARIAA). The program aims to help build the resilience of vulnerable populations and their livelihoods in three climate change "hot spots" in Africa and Asia by supporting research aimed at informing adaptation policy and practice. The program is supporting this collaborative and transdisciplinary research by funding consortia to undertake programs of research in each of these hot spots.

To inform the development of the CARIAA program, studies were commissioned to identify and characterize the state of knowledge on biophysical impacts, social vulnerability, and adaptation policy and practice in the three hot spots. These studies are profiled in this special edition. In this editorial, we identify and define the CARIAA hot spot regions and describe CARIAA's collaborative and transdisciplinary approach to adaptation research, providing a framework for the studies included in this special issue.

\section{Using a climate change "hot spot" approach}

The biophysical environment is a key factor in the vulnerability of poor people (Smit et al. 2001), who often inhabit areas where exposure to climate risks is disproportionately higher. The livelihoods of poor inhabitants of these environments are often also under great threat from the biophysical impacts of climate change. Over and above the physical and economic costs of these impacts on the lives of the poor, there is a need to better understand the risks climate change poses to social systems and cultures which, as Adger et al. (2007) argue, give meaning and value to peoples' lives. These vulnerabilities do not exist discretely but overlap in complex ways. Better understanding of these types of risks-including those exacerbated by maladaptative planning and practices-will be critical to improving climate change adaptation research, with implications for operationalizing adaptation options.

CARIAA's approach to addressing these overlapping vulnerabilities is to focus efforts on climate change "hot spots," defined as an area where a strong climate change signal is combined with a large concentration of vulnerable, poor, or marginalized people. Similar approaches to assessing or mapping areas where climate hazard and social vulnerability intersect have been used in other recent studies (see Thornton et al. 2008; Ehrhart et al. 2009; Hare et al. 2011). The three hot spots defined by the CARIAA program are:

- Semiarid regions in Africa and parts of South and Central Asia,

- Deltas in Africa and South Asia, and

- Glacier- and snowpack-dependent river basins in the Himalayas

Climate change is expected to have serious impacts for people living within these hot spot areas-from loss of food crop yields to disasters such as flooding, fluctuations in seasonal water availability, or other systemic effects. Through this hot spot approach, the CARIAA program will support research and collaboration across regions and continents, which we expect will yield new types of analysis, new opportunities for comparison, and potential for scaling innovations up and out to national, regional, and cross-continental scales.

Based on an analysis of the features of each of these hot spots and a consideration of IDRC and DFID programming requirements, CARIAA identified 47 countries that would be considered eligible for activities and that have been included in the studies contained in the papers that follow (see Annex 1). The following sections provide a brief overview of the three hot spots defined by the CARIAA program.

Semiarid regions

These regions are home to approximately 2 billion people, of which $90 \%$ are estimated to live in developing countries (Dobie 2001; UN EMG 2011). Semiarid regions are likely to experience more frequent and intense droughts due to climate change (IPCC 2014). The size of semiarid regions is also expected to increase, with over half of Africa's land area vulnerable to desertification (Boko et al. 2007). Large areas of sub-Saharan Africa and South and Central Asia are marginalized and already under significant stress. The vulnerability of populations in these regions is clear, considering that agriculture contributes $30-40 \%$ of Africa's 
GDP and supports the livelihoods of approximately $65 \%$ of the population (IFPRI 2009). While this last percentage is projected to decrease due to rural-urban migration, food security may be even more at risk if new ways to strengthen the food production and transport systems in the light of adaptation needs are not promoted. In South Asia, there is high dependence on the annual monsoon, which faces disruption under climate change. Furthermore, about $60 \%$ of cultivated area in these regions is rain fed (World Bank 2009), with a possible future increase in this figure in some marginal areas.

\section{Deltas}

Coastal zones are home to more than $60 \%$ of the human population (a figure expected to climb to $75 \%$ by 2025) and are at the same time among the richest regions of the Earth in terms of biodiversity. Ericson et al. (2006) estimated that nearly 300 million people inhabit 40 major deltas around the world, including all the large mega-deltas. Some mega-deltas, for example the Mekong, the Ganges-Brahmaputra-Meghna, the Niger, and the Nile, shape the social, economic, and cultural life of entire nations. Deltas have become areas of growing economic importance, reflected by increasing infrastructure density (Nicholls et al. 2008) and ecosystem fragmentation (Ramachandran et al. 2010), and whose dynamics depend critically on human activities and climatic event regulating upstream sediment and water transport. This determines a mixture of climatic and non-climatic factors at the origin of vulnerability of communities living in deltas (Bianchi and Allison 2009; Deltares 2009).

In South Asia, key problems affecting deltas include relative sea-level rise (due to subsidence), decrease in sediment supply (due to dams, sand and water mining and partially to change in river flows due to climatic factors), increase in groundwater salinity levels, and deteriorating water quality; aggressive land loss and erosion due to concurrent increase in frequency of floods, storm surges, and extreme cyclonic events (Deltares 2009) coupled with loss of natural protections ranging from mangrove forest cover (Spalding et al. 2010), sand dune complexes (Saito et al. 2007) to entire island such as in the Sundarbans in India and Bangladesh (Gopal 2013). All of these factors exacerbate the loss of lives during extreme events, loss of agricultural land, damages to other economic activities such as fisheries (Raha et al. 2012), loss of property and infrastructure (Nicholls et al. 2008; Nicholls 2011), and loss of biodiversity and species abundance. In Africa, the main interconnected phenomena affecting deltas are changes in freshwater availability and sediment transport due to heavy upstream damming and changing rainfall patterns (for example, in the Tana, the Zambesi and the
Nile), subsidence and coastal erosion (Nile, Mouloya; Snoussi et al. 2008; Nicholls 2011), saline and other chemical intrusions (Niger), flooding (Cameroon; Munji et al. 2013), and loss of biodiversity.

There are strong causal links between the alteration of deltaic dynamics and the utilization of natural resources in lands upstream (often semiarid in the case of countries selected by CARIAA), and changes in the precipitation regimes in the mountain regions from where the rivers feeding the deltas generate. The understanding and tackling of vulnerability in deltas must therefore be done in conjunction with the other two hot spots.

Glacier- and snowpack-dependent river basins

More than one-sixth of the world's population lives in glacier- or snowmelt-fed river basins, which will be affected by significant decrease in water stored in glaciers and snowpack (Kundzewicz et al. 2007). In the Himalayas, this is of particular concern considering the large population that depends on glacial melt water (IPCC 2007; McDowell et al. 2014). For example, more than 1.5 billion people living in the floodplains of the Ganges, Indus, and Brahmaputra are dependent on the Himalayan water system. The Hindu Kush-Himalayan $(\mathrm{HKH})$ region, including the Tibetan plateau, functions as a complex interaction of atmospheric, cryospheric, hydrological, geological, and environmental processes and bears significant influence on the region's biological diversity, climate, and water cycles (Yao et al. 2011). The region also plays a prominent role in generating the Asian monsoon system that sustains one of the largest populations on earth (Boos and Kuang 2010). The ecosystem services from the Himalayan river basins also form the basis for a substantial portion of the region's total gross domestic product (GDP; Eriksson et al. 2009).

Seasonal meltwater from the Himalayan glaciers is one of the main sources of freshwater reserves that directly sustain people living in many parts of the region, especially in arid and semiarid areas (Lutz et al. 2014). At varying degrees and times, about 1.3 billion people living in the Himalayan river basins rely on both meltwater and monsoon waters to sustain their livelihoods, mainly for irrigation, drinking, sanitation, and industrial uses (Eriksson et al. 2009; Sharma et al. 2007; Xu et al. 2009). Net irrigation water demand is high in this region, but per capita water availability is very low-around 2,000-3,000 $\mathrm{m}^{3-}$ /capita/year-which is far less than the world average of $8,549 \mathrm{~m}^{3} /$ capita/year (Ramanathan et al. 2008). Based on a projected estimate of glacier area in 2050, it is thought that declining water availability will eventually threaten some 70 million people with food insecurity (Immerzeel et al. 2010). Part of the water flow in these river basins depends 
on snow and glacial melt to perennial rivers, such as the Ganges, Indus, Brahmaputra, Mekong, and Yangtze. In turn, the amount of snow- and ice melt influences runoff into lowland rivers and the amounts of water recharging river-fed aquifers. The greatest dependence is in arid and semiarid areas, such as western China, northeastern Afghanistan, Uzbekistan, and parts of Pakistan (Immerzeel et al. 2010; Thayyen et al. 2007).

\section{Collaborating across disciplines: introducing the seven studies in this special issue}

The papers gathered in this special issue focus on these three high-risk climate change "hot spots." Together, the papers examine the biophysical and sociopolitical dimensions of climate change impacts across a breadth of literature while addressing the following questions:

- What is a systematic yet pragmatic approach to finding answers in such a multidisciplinary field?

- How can we frame the relationships between biophysical impacts, social vulnerabilities, and policy and practice issues?

- What are the key issues in terms of the vulnerability of poor people's livelihoods to climate change?

- How can we identify potential solutions in the face of uncertainty with a focus on long-term adaptation planning and building local communities' resilience to climate change?

- What are the best entry points for uptake of research results to assist the effective use of evidence generated to inform policy responses and practice on adaptation in developing countries?

The CARIAA program recognizes the need to draw on a wide range of disciplinary expertise to address these questions, and more broadly to respond to what some have called the "disciplinary challenge" of adaptation research (Mustelin et al. 2013). This is reflected in the program's consortium model, which brings together groups of institutions in each hot spot to conduct a collaborative program of research.

This recognition also informed the structure of the studies included in this special issue: rather than studies on individual hot spots, the papers each address one of the various facets of adaptation in the three hot spots, namely biophysical impacts, social vulnerability, and adaptation policy and practice. In the case of the papers covering adaptation in policy and practice in the hot spots, one study per hot spot was undertaken to allow greater scope for contextualizing findings within the hot spot in question. The methodology for addressing these questions and synthesizing results was also a key consideration that required a particular set of expertise and is covered within this special issue. Given the inherent connections between the biophysical, social, and political aspects adaptation in the hot spots, authors of the studies worked in close consultation to produce the comprehensive and interlinked studies that follow in this special issue. The papers come together as outlined in the following brief overview of the rest of this special issue.

Exploring the literature on adaptation and framing results

Berrang-Ford et al. (2015) open the special issue by describing the methodological challenges of synthesizing research on climate change adaptation. Building upon an emerging scholarship in this area in a climate change context (e.g., Berrang-Ford et al. 2011; Ford et al. 2011; Lesnikowski et al. 2013), they critically examine systematic review-based methodologies in terms of potential applications to questions in the human dimensions of climate change research field, which, as they point out, is inherently multidisciplinary and in need of significant methodological cross-fertilization. These insights on systematic review in climate change adaptation research informed the approach that other authors in this special issue used in their studies.

Kilroy (2015) employs the systematic review method outlined by Berrang-Ford et al. to characterize existing knowledge on the biophysical impacts of climate change across semiarid zones, mega-deltas, and glacier-fed river basins in Africa and Asia. The paper provides an analysis of the wealth of existing information published since 2006. The review demonstrates the relative abundance of peerreviewed literature available on river basins over megadeltas and lack of relevant studies on Central Asia and select African countries. The paper outlines opportunities to move the research and programming agenda forward particular to each hot spot area.

Major drivers of social vulnerability across socioecological landscapes

Tucker et al. (this issue) review literature on the treatment of social vulnerability to climate change in the hot spots, including the conceptualization and assessment of vulnerability across socio-ecological conditions and different spatial-temporal scales. The paper highlights the diversity of approaches used to measure vulnerability. While broad trends across hot spots emerged from the authors' analysis, it is clear that social vulnerability manifests in complex ways according to local specificities, for example the state's role in adaptation. The state may, for example, inadvertently constrain adaptive capacity in some areas, for 
example through policies to sedentarize pastoralists without adequate support to alternative livelihoods that are suitably "climate smart." Alternatively, the state can play a role in preventing maladaptation and conflicts from transfer of vulnerability from one livelihood group, sector, or region to another. Overall, vulnerability has local, individual impacts, but it is driven by compounding factors at different scales. The authors note that drivers of vulnerability are often correlated with a combination of rapid population and economic growth as well as the presence of significant levels of poverty and weak institutional capacity. This intersection represents a significant gap in adaptation research.

Current trends in policy and practice across three climate change hot spots

Lwasa (this issue) reviews the status of adaptation policy and practice in deltas of Africa and Asia. While adaptation policies seem to be sector-based wish lists, he observes that adaptation practice in the deltas is currently mostly driven by reactions to disasters such as flooding and storms and implemented by local and international non-governmental organizations, with frequently no backup from the policy and planning level. He also raises the need to move from incremental to transformational adaptation, so that vulnerable communities can go beyond reclaiming previous rights-which put them back into the previous position of vulnerability - and implement longterm adaptation. Finally, the paper points out some geographical differences in the actors engaging in the adaptation and policy discourse in various deltas (e.g., mainly state in the case of the Nile, as opposed to a mixture of state and local actors in the Brahmaputra), which can suggest directions for comparative research.

Sud et al. (2015) conduct a similar review for the densely populated glacier-fed river basins of South Asia. Flood control and trans-boundary water management are the key issues in this hot spot. The authors review activities and objectives at institutional, policy, and practice levels to determine the region's potential for adaptive governance. While ambiguous goal setting constrains adaptation policy implementation, institutions hold significant capacity for adaptive governance. Adaptation responses and associated documentation are prevalent. The paper illustrates this "policy-practice mismatch" as a potential barrier to adaptive governance and provides potential entry points for discussions with policy makers in the hot spot countries.

Bizikova et al. (2015) conduct a review of the literature to address the gap between adaptation planning at the national level and projects from local to international levels in semiarid regions. National priorities tend to be sector based and overall focus on agriculture water management. The authors reveal the influential role of international agencies in achieving national adaptation planning goals, in the cases where they align. Adaptation projects seem to be supported mostly by international agencies as opposed to national governments, allocated based on vulnerability and ability of the recipient government to manage funds. Projects also do not incorporate particular social issues indicated in national adaptation strategies, such as migration and security. The needs of the most vulnerable are mostly discussed in poverty reduction strategies, but not climate change documentation.

Finally, Ford et al. (this issue) complement the in-depth analyses described above with a broader review of the current status of adaptation initiatives in CARIAA's 47 "hot spot" countries based on a systematic review of peerreviewed and gray literature as well as policy documents. The authors observe that adaptation is the dominant focus of reported initiatives, but that consideration of vulnerable groups in the reported initiatives is negligible. Their analysis also shows that adaptation initiatives are being primarily driven at the national level, with apparent minimal involvement of lower levels of government or collaboration across nations. There is very little work to date across scales and actors to implement adaptation options (Berrang-Ford et al. this issue), and the private sector is absent in adaptation reporting.

Together, the results of this series of reviews, presented in the papers that follow, provide a multi-disciplinary perspective on the state of knowledge of climate change adaptation and resilience in CARIAA's climate change hot spots.

Acknowledgments The papers gathered in this special feature were commissioned by the United Kingdom's Department for International Development and Canada's International Development Research Centre under the Collaborative Adaptation Research Initiative in Africa and Asia (CARIAA).

Open Access This article is distributed under the terms of the Creative Commons Attribution License which permits any use, distribution, and reproduction in any medium, provided the original author(s) and the source are credited.

\section{References}

Adger WN, Agrawala S, Mirza MMQ, Conde C, O’Brien K, Pulhin J, Pulwarty R, Smit B, Takahashi K (2007) Assessment of adaptation practices, options, constraints and capacity. In: Parry ML, Canziani OF, Palutikof JP, van der Linden PJ, Hanson CE (eds) Climate change 2007: impacts, adaptation and vulnerability. Contribution of working group II to the fourth assessment report of the Intergovernmental Panel on Climate Change. Cambridge University Press, Cambridge, pp 717-743

Berrang-Ford L, Ford JD, Paterson J (2011) Are we adapting to climate change? Glob Environ Change 21(1):25-33. doi:10. 1016/j.gloenvcha.2010.09.012 
Berrang-Ford L, Pearce T, Ford JD (2015) Systematic review approaches for climate change adaptation research. Reg Environ Change. doi:10.1007/s10113-014-0708-7

Biagini B, Bierbaum R, Stults M, Dobardzic S, McNeeley SM (2014) A typology of adaptation actions: a global look at climate adaptation actions financed through the Global Environment Facility. Glob Environ Change 25:97-108. doi:10.1016/j.gloenv cha.2014.01.003

Bianchi TS, Allison MA (2009) Large-river delta-front estuaries as natural "recorders" of global environmental change. PNAS 106(20):8085-8092. doi:10.1073/pnas.0812878106

Bizikova L, Parry JE, Karami J, Echevierria D (2015) Review of key initiatives and approaches to adaptation planning at the national level in semi-arid areas. Reg Environ Change. doi:10.1007/ s10113-014-0710-0

Boko M, Niang I, Nyong A, Vogel C, Githeko A, Medany M, OsmanElasha B, Tabo R, Yanda P (2007) Africa. In: Parry ML, Canziani OF, Palutikof JP, van der Linden PJ, Hanson CE (eds) Climate change 2007: impacts, adaptation and vulnerability. Contribution of working group II to the fourth assessment report of the Intergovernmental Panel on Climate Change. Cambridge University Press, Cambridge, pp 433-467

Boos WR, Kuang Z (2010) Dominant control of South Asian monsoon by orographic insulation versus plateau heating. Nature 463:218-222. doi:10.1038/nature08707

Costello A, Abbas M, Allen A, Ball S, Bell S, Bellamy R, Friel S, Groce N, Johnson A, Kett M, Lee M, Levy C, Maslin M, McCoy D, McGuire B, Montgomery H, Napier D, Pagel C, Patel J, de Oliveira JAP, Redclift N, Rees H, Rogger D, Scott J, Stephenson J, Twigg J, Wolff J, Patterson C (2009) Managing the health effects of climate change. Lancet 373:1693-1733. doi:10.1016/ S0140-6736(09)60935-1

Deltares (2009) Towards sustainable development of deltas, estuaries and coastal zones. Description of eight selected deltas. Retrieved from www.deltares.nl/xmlpages/tan/files?p_file_id=13321

Dimitrov RS (2010) Inside UN climate change negotiations: the Copenhagen conference. Rev Policy Res 27(6):795-821. doi:10. 1111/j.1541-1338.2010.00472.x

Dobie P (2001) Poverty and the drylands. United Nations Development Programme. Drylands Development Centre, Nairobi

Ehrhart C, Thow A, de Blois M, Warhurst A (2009) Humanitarian implications of climate change: mapping emerging trends and risk hot spots. Care Canada and Maplecroft. Retrieved from http://www.care.org/sites/default/files/documents/CC-2009CARE_Human_Implications.pdf

Ericson JP, Vörösmarty CJ, Dingman SL, Ward LG, Meybeck M (2006) Effective sea-level rise and deltas: causes of change and human dimension implications. Glob Planet Change 50:63-82. doi:10.1016/j.gloplacha.2005.07.004

Eriksson M, Xu J, Shrestha AB, Vaidya RA, Nepal S, Sandstörm K (2009) The changing Himalayas: impact of climate change on water resources and livelihoods in the greater Himalayas: perspectives on water and climate change adaptation. International Centre for Integrated Mountain Development, Kathmandu. Retrieved from http://www.worldwatercouncil.org/fileadmin/world_water_council/ documents_old/Library/Publications_and_reports/Climate_Change/ PersPap_01._The_Changing_Himalayas.pdf

Fankhauser S (2010) The costs of adaptation. WIREs Clim Change 1(1):23-30. doi:10.1002/wcc.14

Fankhauser S, Schmidt-Traub G (2011) From adaptation to climateresilient development: the costs of climate-proofing the Millennium Development Goals in Africa. Clim Dev 3(2):94-113. doi:10.1080/17565529.2011.582267

Ford JD, Berrang-Ford L, Bunce A, McKay C, Irwin M, Pearce T (this issue) The status of climate change adaptation in Africa and Asia. Reg Environ Change. doi:10.1007/s10113-014-0648-2
Ford JD, Berrang-Ford L, Paterson J (2011) A systematic review of observed climate change adaptation in developed nations. Clim Change 106(2):327-336. doi:10.1007/s10584-011-0045-5

Gopal B (2013) Future of wetlands in tropical and subtropical Asia, especially in the face of climate change. Aquat Sci 75(1):39-61. doi:10.1007/s00027-011-0247-y

Hare WL, Cramer W, Schaeffer M, Battaglini A, Jaeger CC (2011) Climate hotspots: key vulnerable regions, climate change and limits to warming. Reg Environ Change 11(Suppl 1):1-13. doi:10.1007/s10113-010-0195-4

IFPRI (2009) Agriculture's critical role in Africa's development. media briefing on GM crops for African farmers. Retrieved from http://www.ifpri.org/publication/agriculture-s-critical-roleafrica-s-development. Accessed 19 May 2009

Immerzeel WW, Beek LPH, Bierkens MFP (2010) Climate change will affect the Asian water towers. Science 328(5984):1382-1385. doi:10.1126/science. 1183188

IPCC (2007) Climate change 2007: impacts, adaptation and vulnerability. In: Parry ML, Canziani OF, Palutikof JP, van der Linden PJ, Hanson CE (eds) Contribution of working group II to the fourth assessment report of the IPCC. Cambridge University Press, Cambridge, p 976

IPCC (2014) Climate change 2014: impacts, adaptation and vulnerability. Part A: global and sectoral aspects. In: Field CB, Barros VR, Dokken DJ, Mach KJ, Mastrandrea MD, Bilir TE, Chatterjee M, Ebi KL, Estrada YO, Genova RC, Girma B, Kissel ES, Levy AN, MacCracken S, Mastrandrea PR, White LL (eds) Contribution of working group II to the fifth assessment report of the Intergovernmental Panel on Climate Change. Cambridge University Press, Cambridge

Kundzewicz ZW, Mata LJ, Arnell NW, Döll P, Kabat P, Jiménez B, Miller KA, Oki T, Sen Z, Shiklomanov IA (2007) Freshwater resources and their management. In: Parry ML, Canziani OF, Palutikof JP, van der Linden PJ, Hanson CE (eds) Climate change 2007: impacts, adaptation and vulnerability. Contribution of working group II to the fourth assessment report of the Intergovernmental Panel on Climate Change. Cambridge University Press, Cambridge, pp 173-210

Kilroy G (2015) A review of the biophysical impacts of climate change in three hotspot regions in Africa and Asia. Reg Environ Change. doi:10.1007/s10113-014-0709-6

Lesnikowski AC, Ford JD, Berrang-Ford L, Barrera M, Berry P, Henderson J, Heymann SJ (2013) National-level factors affecting planned, public adaptation to health impacts of climate change. Glob Environ Change 23(5):1153-1163. doi:10.1016/j. gloenvcha.2013.04.008

Loarie SR, Duffy PB, Hamilton H, Asner GP, Field CB, Ackerly DD (2009) The velocity of climate change. Nature 462(7276): 1052-1055. doi:10.1038/nature08649

Lutz AF, Immerzeel WW, Shrestha AB, Bierkens MFP (2014) Consistent increase in high Asia's runoff due to increasing glacier melt and precipitation. Nat Clim Change 4:587-592. doi:10.1038/nclimate2237

Lwasa $\mathrm{S}$ (this issue) A systematic review of research on climate change adaptation policy and practice in Africa and South Asia deltas. Reg Environ Change. doi:10.1007/s10113-014-0715-8

McDowell G, Stephenson E, Ford JD (2014) Adaptation to climate change in glaciated mountain regions. Clim Chang 126(1-2), pp. 77-91. doi:10.1007/s10584-014-1215-Z

Mertz O, Halsnaes K, Olesen JE, Rasmussen K (2009) Adaptation to climate change in developing countries. Environ Manage 43(5):743-752. doi:10.1007/s00267-008-9259-3

Munji CA, Mekou YB, Nkwatoh AF, Idinoba ME, Somorin OA, Sonwa DJ (2013) Vulnerability to coastal flooding and response strategies: the case of settlements in Cameroon mangrove forests. Environ Dev 5:54-72. doi:10.1016/j.envdev.2012.10.002 
Mustelin J, Kuruppu N, Kramer AM, Daron J, de Bruin K, Noriega GA (2013) Climate adaptation research for the next generation. Clim Dev 5(3):189-193. doi:10.1080/17565529.2013.812953

Nicholls RJ (2011) Planning for the impacts of sea level rise. Oceanography 24(2):144-157. doi:10.5670/oceanog.2011.34

Nicholls RJ, Hanson S, Herweijer C, Patmore N, Hallegatte S, Corfee-Morlot J, Château J, Muir-Wood R (2008) Ranking port cities with high exposure and vulnerability to climate extremes: exposure estimates. OECD Environment Working Papers No. 1, OECD Publishing. doi:10.1787/011766488208

Raha A, Das S, Banerjee K, Mitra A (2012) Climate change impacts on Indian Sundarbans: a time series analysis (1924-2008). Biodivers Conserv 21(5):1289-1307. doi:10.1007/s10531-0120260-z

Ramachandran R, Ramachandran P, Lakshmi A (eds) (2010) Deltas: coastal vulnerability and management. Proceedings of the 2009 international workshop, Institute for Ocean Management, Anna University Chennai, Chennai. Retrieved from http://www.loicz. org/imperia/md/content/loicz/report/delta_workshop_report_ final_15may2010.pdf

Ramanathan V, Agrawal H, Akimoto M, et al. (2008) Atmospheric brown clouds: regional assessment report with focus on Asia. United Nations Environment Programme, Nairobi, Kenya. Retrieved from http://www.unep.org/pdf/ABCSummaryFinal. pdf

Ranger N (2013) Topic guide. Adaptation: decision making under uncertainty. Evidence on demand, UK. doi:10.12774/eod_tg02. june2013.ranger

Saito Y, Chaimanee N, Jarupongsakul T, Syvitski JPM (2007) Shrinking mega-deltas in Asia: sea-level rise and sediment reduction impacts from case study of the Chao Phraya delta. Newsletter of the IGBP/IHDP Land Ocean Interaction in the Coastal Zone 2:3-9

Sharma E, Bhuchar S, Xing MA, Kothyari BP (2007) Land use change and its impact on hydro-ecological linkages in Himalayan watersheds. Trop Ecol 48(2):151-161

Smit B, Pilifosova O, Burton I, Challenger B, Huq S, Klein RJT, Yohe G (2001) Adaptation to climate change in the context of sustainable development and equity. In: McCarthy JJ, Canziani OF, Leary NA, Dokken DJ, White KS (eds) Climate change 2001: impacts, adaptation and vulnerability. Contribution of working group II to the third assessment report of the Intergovernmental Panel on Climate Change. Cambridge University Press, Cambridge, pp 877-912

Smith J, Schellnhuber H-J, Mirza MMQ (2001) Vulnerability to climate change and reasons for concern: a synthesis. In: McCarthy JJ, Canziani OF, Leary NA, Dokken DJ, White KS (eds) Climate change 2001: impacts, adaptation and vulnerability. Contribution of working group II to the third assessment report of the Intergovernmental Panel on Climate Change. Cambridge University Press, Cambridge, pp 915-967

Snoussi M, Ouchani T, Niazi S (2008) Vulnerability assessment of the impact of sea-level rise and flooding on the Moroccan coast: the case of the Mediterranean eastern zone. Estuar Coast Shelf Sci 77(2):206-213. doi:10.1016/j.ecss.2007.09.02

Spalding M, Kainuma M, Collins L (2010) World atlas of Mangroves. A collaborative project of ITTO, ISME, FAO, UNEP-WCMC, UNESCO-MAB, UNU-INWEH and TNC. Earthscan, London

Sud R, Mishra A, Varma N, Bhadwal, S (2015) Adaptation policy and practice in densely populated glacier-fed river basins of South Asia: a systematic review. Reg Environ Change. doi:10.1007/ s10113-014-0711-z

Thayyen RJ, Gergan JT, Dobhal DP (2007) Role of glaciers and snow cover on headwater river hydrology in monsoon regime-microscale study of Din Gad catchment, Garhwal Himalaya, India. Curr Sci 92(3):376-382

Thornton PK, Jones PG, Owiyo T, Kruska RL, Herrero M, Orindi V, Bhadwal S, Kristjanson P, Notenbaert A, Bekele N, Omolo A (2008) Climate change and poverty in Africa: mapping hotspots of vulnerability. Afr J Resour Econ 21(1):24-44

Tucker J, Few R, Conway D, Daoud M, Oates N, Mtisi S, Matheson S (this issue) Social vulnerability in three high poverty climate change hotspots: what does the climate change literature tell us? Reg Environ Change. doi:10.1007/s10113-014-0741-6

UN EMG (2011) Global drylands: a UN system-wide response. Environment Management Group of the United Nations Geneva. Retrieved from http://www.unccd.int/Lists/SiteDocumentLi brary/Publications/Global_Drylands_Full_Report.pdf

UNEP (2012) The business case for the green economy. Sustainable return on investment. Retrieved from http://www.unep.org/ greeneconomy/Portals/88/documents/partnerships/UNEP\% 20BCGE\%20A4.pdf

World Bank (2009) Economics of adaptation to climate changesynthesis report. The World Bank Group, Washington. Retrieved from http://siteresources.worldbank.org/EXTCC/Resources/ EACC_FinalSynthesisReport0803_2010.pdf

World Bank (2012) Turn down the heat, why a 4 degree $C$ warmer world must be avoided. A report for the World Bank by the Potsdam Institute for Climate Impact Research and Climate Analytics, Washington. Retrieved from http://www.climateana lytics.org/publications/turn-down-heat-why- $4 \% \mathrm{C} 2 \% \mathrm{~B} 0 \mathrm{c}$-war mer-world-must-be-avoided

Xu J, Shrestha A, Eriksson M (2009) Climate change and its impacts on glaciers and water resource management in the Himalayan Region. In: Braun LN, Hagg W, Severskiy IV, Young G (eds) Assessment of snow, glacier and water resources in Asia: Selected papers from the Workshop in Almaty, Kazakhstan, 2006. IHP/HWRP-BERICHTE Koblenz, Heft 8, pp 44-54 Retrieved from http://www.mtnforum.org/sites/default/files/pub lication/files/5412.pdf

Yao TD, Thompson LG, Musbrugger V, Ma YM, Zhang F, Yang XX, Joswiak D (2011) Third pole environment. UNESCO-SCOPEUNEP Policy Briefs Series. UNESCO-SCOPE-UNEP, Paris. Retrieved from http://www.scopenvironment.org/unesco/ 110630-Web\%20USUPB13\%20Third\%20Pole.pdf 